\title{
AZ ÓKORI MEZOPOTÁMIA KATONÁI - 1. RÉSZ
}

\section{Szerzők:}

Fejes Zsolt (PhD)

Magyar Honvédség Egészségügyi Központ

Helyes Marcell

Karl-Franzens Universitat (Ausztria)

Mihók Sándor (Dr. Jur.)

nyugalmazott jogtanácsos

Első szerző e-mail címe:

zsoltfejesdr@yahoo.com

\section{Lektorok:}

Kóródi Gyula (Prof. Dr.)

Nemzeti Közszolgálati Egyetem

Rikk János (PhD)

Kodolányi János Egyetem

...és további két anonim lektor

\begin{abstract}
Absztrakt
Jelen tanulmányban - egy cikksorozat első részeként - az ókori Közel-Kelet birodalmai közül Mezopotámia hadseregeit tekintjük át - vázlatosan - a Kr. e III. évezredtől a Kr. e 7. századig, különös tekintettel a katonák juttatásaira. Először bemutatjuk a kor jelentős hadseregeinek kialakulási folyamatát, majd részletesen ismertetjük a sumér és akkád kor, illetve az óbabiloni birodalom hadseregeinek jellemzőit. A cikksorozat következő részében ismertetjük az újasszír birodalom hadseregeinek jellemzőit. Részletesen kitérünk a korszak sorozott és önkéntességen alapuló hadseregeiben szolgáló - köz, hivatásos és zsoldos - katonák „pénzbeli” (Lóránt, 2018), és természetbeni juttatásainak ismertetésére, valamint áttekintjük a sérült vagy harcban elesett katonák özvegyeinek és árváinak kezdetleges ellátási rendszerét is.
\end{abstract}

Kulcsszavak: Mezopotámia, Óbabilon, Hammurapi

Diszciplinák: történelem, hadtudomány

\section{Abstract \\ SOLDIERS OF THE ANCIENT MESOPOTAMIA - PART 1}

In this study - as the first part of a series of articles - we overview - schematically - the armies of Mesopotamia from the ancient empires of the Middle East from the 3rd millennium $\mathrm{BC}$ until the 7th century $\mathrm{BC}$, particularly regarding the allowances of the soldiers. Firstly, we demonstrate the process about the evolving of the significant armies of the time. Secondly, we describe the characteristics of armies of the Sumer and Akkadian time as well as Old Babylon's military forces in detail. In the following part of our series of articles we review the characteristics of the armies of the Neo-Assyrian Empire. We describe in detail the monetary 
allowances and contributions in kind of the enlisted and voluntary -private, regular and mercenary- soldiers of the age, furthermore we overview the service system for widows and orphans of soldiers, who were injured or died in battle.

Keywords: Mesopotamia, Old Babylon, Hammurapi

Disciplines: history, military science

Fejes Zsolt, Helyes Marcell és Mihók Sándor (2020): Az ókori Mezopotámia katonái - 1. rész.

Lélektan és hadviselés - interdiszciplináris folyóirat, II. évf. 2020/1. szám. 31-44. doi: 10.35404/LH.2020.1.31

\section{Bevezető gondolatok}

Az ókori Mezopotámia bemutatását megelőzően tisztázni szükséges az ókori KözelKelet meghatározását, amely nem egyszerű feladat, mivel az ókori Közel-Kelet tulajdonképpen egy politikai és tudománytörténeti fogalom, melynek határai nem húzhatók meg pontosan sem térben, sem pedig időben. Az ókortörténetben a klasszikus „Oriens” fogalmára alapozva alakult ki az „Oriens antiquus”, az antik világ Keletje: Szíria-Mezopotámia, Egyiptom, Anatólia, Armenia, Nyugat-Irán vagyis az egykor az Akhaimenida dinasztia uralma alá tartozó hatalmas térség.

Az ókori Közel-Kelethez sorolhatók a következő mai országok/térségek: KisÁzsia, Kelet-Törökország (Anatólia), Örmény-felföld, Transz-Kaukázia, a Levante (Szíria, Libanon, Palesztina és Izrael), Arábia, a Folyamköz/Mezopotámia (Szíriának az Eufrátesztől keletre eső része és Irak), a Perzsa-öböl térsége, valamint Irán.
A középkori utazók a Bibliában leírt események helyszíneit keresték a Közel-Keleten és kialakult a „Bibliai Kelet” évszázadokig használt fogalma, amelyet közel 150 éve pontosított a régészeti feltárások és az írásos emlékek megfejtésére támaszkodó „Édenkertmitosz”. Az Édenkert-mítosz keretén belül a történetírás meg akarta határozni a legősibb közel-keleti kultúrák helyét az egyetemes történelemben. Az Édenkert-mítosz tulajdonképpen három vagy négy nagy paradigma, amelyekben közös, hogy a történelem kezdetének színterét Mezopotámiában látták. A XX. század közepén a bibliai mítosz helyét egy újabb keletű metaforikus kifejezés foglalta el. Napjaink történetírásban különösen népszerűvé vált a „termékeny félhold” fogalma (1. ábra). Vonzerejét lényegében a képzettársítás adja: a Nílus völgyétől Szírián át a Perzsa-öbölig húzódó terület - mai térképeinken szemlélve - valóban emlékeztet valamelyest a holdsarlóra, ahogyan a Hold, a harmadik negyedben, a Közel-Keleten látható. Megjegyzést érdemel, hogy ennek a „félholdnak” a három nagy tájegysége - a Földközi-tenger 
keleti partvidéke (Levante), a szíriai és északmezopotámiai sztyeppe, továbbá DélMezopotámia és Egyiptom - azonban nagyon eltérő feltételeket kínált az emberi élethez.

\section{1. ábra: A „termékeny félhold" földrajzi elhelyez-}

kedése. Forrás: Net1.

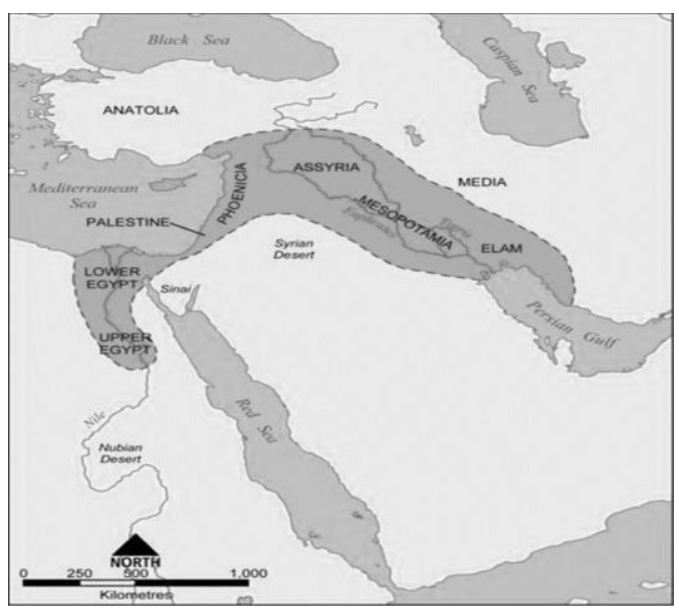

A tanulmányban az ókori Mezopotámia mai tudományos nyelvben elfogadott meghatározását vesszük alapul, mely szerint Mezopotámia a Tigris és Eufrátesz folyók által közrezárt terület egészét jelöli. E terület nagyjából a mai Irak állam, északnyugati része azonban Szíriához és Törökországhoz tartozik (Komoróczy, s.a.).

Figyelemmel a terjedelmi korlátokra, a tanulmányban - a teljesség igénye nélkül - csak az agadei (akkád) birodalom (kb. Kr. e. 24-22. század), az óbabiloni kor (Kr. e. 20-17. század) és az újasszír katonai nagyhatalom (Kr. e. 9-7. század) hadseregeiben szolgáló katonák juttatásait tekintjük át.
Az újasszír kor alapvetően egy nyelvészeti kategória, amely az akkád nyelv aszszír dialektusának utolsó szakaszát jelöli a történettudomány pedig azt az államalakulatot érti ezen fogalom alatt, amelyből e dialektus írott forrásai származnak (Vér, 2011).

A katonák juttatásait a fennmaradt források tükrében úgy mutatjuk be, hogy szolgálatukért - állomány-kategóriánként - miben részesültek (napi élelmezési fejadag, részesedés a zsákmányból, egyéb juttatások). Kiemelt figyelmet fordítunk annak bemutatására, hogy a korszak uralkodói milyen föld(birtok)juttatással igyekeztek „magukhoz láncolni” harcosaikat. Ehhez szorosan kapcsolódik a sérült katonák, a harcban elesettek özvegyeinek, árváinak az ellátása, melynek vázlatos áttekintése rávilágít arra, hogy a csere és kölcsönhatás, az átvétel és a továbbadás révén a korai ókori Közel-Keletrôl számos (jogi) intézmény került át a hellén és a római világba, majd közvetítésükkel Európa jogi kultúrájába (Hajdú és társai, 1991).

Nem zárhatjuk ki annak a lehetőségét, hogy kultúránk, s ezen belül jogi kultúránk szabir öröksége révén közvetlen, szerves rokonságban lehet az északmezopotámiai vagy a tágabb értelmú ókori keleti (közel-keleti) hagyományokkal (is). Lásd: Szádeczky-Kardoss (2012). 


\section{Az ókori Közel-Kelet}

\section{hadseregeinek kialakulása}

Az emberek között zajló összeütközések, fegyveres konfliktusok, vagyis a háborúk egyidősek az emberiséggel. A nagyobb embercsoportok közötti fegyveres küzdelemre vonatkozó legkorábbi régészeti adataink a mezolitikum, vagyis a kőkor középső időszakából (Kr. e. 11000-6000 körül) származnak.

Ebben az időszakban a törzsek közötti harc fegyverei és módszerei alapvetően megegyeztek a vadászatéval, a harcosok pedig azonosak voltak a vadászokkal. A közhatalom és benne a katonai hatalom még nem vált külön a néphatalomtól. A hadsereg azonos a néppel, a hadvezérek a törzsfőkkel és nemzetségfőkkel, akik ekkor a hadivállalkozásokat még csak ,alkalmi megbízásként” vezették (Hahn, 1963).

Az ókori közel-keleti civilizációk rézkőkorszak idejétől fennmaradt (Kr. e. 3500 körüli) ábrázolásain azonban már megjelentek a harcosokból katonákká vált embercsoportot ábrázoló „oroszlánvadászat-sztéléke” (dombormúves-díszítésű, feliratos kőtáblák).

Ezek közül a legjelentősebb és legkorábbi harci jeleneteket ábrázoló „katonai” tárgyi emlékünk Éannatum, Lagas királyának sztéléje, az ún. „Keselyü-sztéle” (Kr. e. 2450 k.) amely az uralkodónak a szomszédos Umma város feletti „fényes” győzelmét örökíti meg. A domborművön elöl halad a király, mögötte előreszegezett lándzsákkal nyomulnak a bőrpajzsos harcosok, átgázolva a legyőzött ellenség ruhátlan holttestein (Rajkó és S. Nagy, 2009).
Az ókori közel-keleti társadalmak kialakulásának meghatározó fordulópontjának tekinthetjük a föld és a nyájtulajdon kialakulásán túl a fémek - előbb a réz, majd a réz és ón vagy ólom ötvözetéből készített bronz - felfedezését. A Kr. e. III. évezredben, amikor a réz és bronzöntés technikája elérte azt a fejlettségi fokot, hogy ezekből a fémekből már tartós, használható fegyvereket és szerszámokat is lehetett készíteni, a földmûvelés központjai áthelyeződtek a szubtropikus övezet nagy folyamainak, a Tigrisnek, az Eufrátesznek és a Nílusnak természetesen öntözött és mesterségesen még nagyobb területen öntözhető síkságaira. Ezeken a területeken jöttek létre az első, megerősített városok, a legősibb - kisebb-nagyobb területű - államok központjai.

Mezopotámiában a főpap királyok képesek voltak rákényszeríteni a faluközösségek lakosságát termésük egy hányadának beszolgáltatására. Ebből fedezni lehetett a királyi udvar, a tisztviselők és a papság továbbá a termelőmunka alól felmentett kéz és fegyverművesek eltartását. Létrejöttek az erősen központosított ókori keleti despotikus monarchiák, amelyek gazdasági és politikai viszonyai határozták meg hadügyeik, hadseregük és hadművészetük jellegét és színvonalát.

Figyelemmel arra, hogy a sumér városállamokban a főpap (al)királyok (enszik, lugalok) az uralmuk alatt álló területek erőforrásainak korlátlan urai voltak, a fegyverkészítés is az ô kizárólagos monopóliumuk volt. A legjobb minőségű rézből, illetve bronzból készült fegyverekkel csak azok rendelkezhettek, akiket ők láttak el. Elméletben még minden férfi hadköteles volt - a hadsereg azonos a felfegyverzett néppel -, de a hadsereg már 
királyi hadsereg, a katonai szolgálat pedig ugyanolyan robot, kötelesség volt, mint a királyi vagy papi földeken, a királyi műhelyekben és építkezéseken végzett munka (Hahn, 1963). Így az ókori Közel-Kelet államai fegyveres védelmi szervezete tekintetében a legősibb intézménynek a hadsereget tekintjük, mely nélkül az állam - és főleg egy jelentôs állam - nem léphetett a történelem színpadára.

Ezeknek a hadseregeknek számos fajtája és közbensô fejlődési foka létezett. A korai korszakról általánosságban az mondható, hogy döntően kevéssé képzett, tömeges, „ad hoc” haderők jellemezték, melyek közül időrőlidőre kimagaslottak a legerőteljesebb és legstabilabb formát jelentő, jól képzett, optimális létszámú, „quasi bivatásos” haderők, vagy haderőrészek (Farkas, 2016). A háborúk közvetlen gazdasági oka pedig a földek, csatornák, értékes nyersanyagok, nemesfémek és rabszolgák megszerzése volt.

\section{A sumér és akkád kor}

\section{hadseregei és hadviselése}

Az egy kultúrkört alkotó Mezopotámia uralmáért folyó történet alapvetően Babilónia és Asszíria története (Dávid, 1926). Ez közel 100 város, 6-7 birodalom, mintegy tíz nép és ötezer év históriája. Mindez egy 1000-1200 kilométer hosszú és 150-200 kilométer széles, balra hajló területen, az előzőekben már ismertetett „termékeny félholdban” (Lóránt, 2018).

A Tigris és Eufrátesz vizével öntözött, csatornákban dús és termékeny síkság legősibb általunk ismert lakói a sumérek voltak. A su- mér terület - erős fallal körülvett - városállamai a csatornák és szántóföldek feletti uralomért már a Kr. e. III. évezred derekán szinte állandóan háborúskodtak egymással. Ebben a korban a nemzetségi szervezet hagyományainak megfelelően a városok teljes férfilakossága alkotta a hadsereget. A városállamok királyai emellett csekély számú, állandó királyi sereggel is rendelkeztek (Hahn, 1963).

A sumér településeken létrejöttek a lándzsások csapatai, amelyek tervszerű kiképzésben részesültek, képesek voltak csatárláncban előrenyomulni és harcolni, illetve pajzsaik védelmében ellenállni az ellenség támadásának. Ezzel első ízben jelent meg a fegyveres küzdelemben a falanx (nehéz fegyverzetű gyalogság, több sorból álló zárt egység). Ekkor már a fegyelem, az állóképesség, a kiképzettség, a harci szellem győzedelmeskedett a háborúkban, demonstrálva a technika és a stratégiai elképzelések szoros összefüggését.

A harcmezô új szereplőjének megjelenése ugyancsak a sumér kultúrához kötődik: szamár vontatta harci kocsik támogatták a lándzsásokat (2. ábra).

„A lovat a sumérek még nem ismerték, arra nem volt külön szavuk, leginkább »hegyi szamárnaku nevezték, ami a ló hurri vagy kassu származására utal. Mezopotámiában a ló legkorábban a III. évezred végén jelent meg és sokáig csak luxusállatként tartották, mivel egy ló áráért kb. 50 rabszolgát lehetett vásárolni” (Klíma, 1983, 121-122.). 
2. ábra: Sumér szekér ábrázolása. Forrás: Net2.

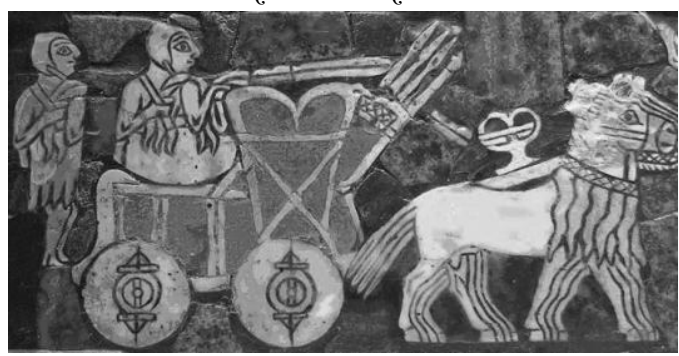

A kezdetleges harci kocsi óriási mértékben megnövelte a harcoló sereg manőverező képességét, ugyanakkor felvetette az összehangolás igényét és ezzel jelentősen megnövelte a hadvezér szerepét (Nagy, 2014).

Az „egyház és az állam szétválasztása” a suméroknál viszonylag korán megtörtént. Kisben az uralkodó palotáját már a Kr. e. 27. század elején a főpap templomától - székhelyétôl - elkülönítve építették fel. Ezzel a papi fejedelem (,patiszu”) az isteni uralkodó utáni második legnagyobb méltósággá - és földbirtokossá - vált.

Sarrukín, a Kr. e. III. évezred első felében uralkodó legendás király Kis papsága kegyéből nyerte el a főpohárnoki tisztséget - lényegében a királyi testőrség parancsnoki beosztását -, majd letaszította trónjáról az akkori törvényes uralkodót. Ezt követően a győzedelmes Sarrukín megalapította Agade városát - melynek pontos helye mindmáig ismeretlen - a „Kis királya” cím mellé felvette az „Akkád királya”, az „ország királya” és a „mindenség királya” címet is. Létrehozta az elsô sémi birodalmat, amely közel két évszázadig (kb. Kr. e. 2350-2150) állt fenn (Klíma, 1983).
Mezopotámiában a hadviselés első nagy korszaka egyértelműen Sarrukín uralkodásához köthető. Az uralkodót egyes történészek a világtörténelem első imperialistájának tartják, mivel nagyhatalmi célokból hódított a Perzsa-öböltől Szíriáig, Kisázsiáig és Ciprusig.

Sarrukínnak ehhez egyrészt rendelkezésére állt egy állandó és ebben a korban rendkívül erősnek számító hadsereg - egyik feliratában azzal dicsekszik, hogy naponta 5400 (!) férfival ebédel (Richard, 2010) -, másrészt tartalékosok behívásával további harcosokat is hadrendbe tudott állítani tervei megvalósításához (Klíma, 1983). Sarrukín állandó királyi hadseregét - amelynek a neve: „Akik a kenyeret a király (szine) elótt eszilk” volt - 9 zászlóaljba szervezte, minden 600 főt számláló egységet egy ezredes (,gir.nita”) vezetett, a 60 fős század (,nu.banda”) élén a század parancsnok (,pa.pa/sha khattim”) állt. A századok pedig szakaszokból (,"ugala”-ból) álltak.

A katonai arisztokrácia, a nemesek (,niskum”-ok) feltétlen hűségükért és katonai szolgálataikért negyedévente hal és sóellátmányban részesültek továbbá királyi földbirtokot kaptak és ezért cserébe, mint félkatonai egységek, „katonai rendőrök” elfojtották a tartományukban szerveződő lázadásokat (Stillman és Tallis, 1984).

Utódai az agadei, majd a III. Ur-i dinasztia a bürokratikusan megszervezett birodalom megvédésére rendelkeztek be és erős védőfalakat kezdtek építeni a betörő nomádok ellen. Azonban katonai erejük végül elégtelennek bizonyult a nyugatsémi amurru (amorita) törzsek friss erejével szemben. 


\section{Az Óbabiloni Birodalom}

\section{hadserege és katonái}

Az Arábia felől érkező Hammurapi (Kr. e. 1728 - 1686) vezetése alatt álló törzsek öszszetörték az elámiak fennhatóságát és megszüntették a sumérok politikai hatalmát. Az új uralkodó Sumért Akkáddal együtt sémi uralom alatt egyesítette és a birodalmat Babilonból irányította (3. ábra).

3. ábra: Az Óbabilon Birodalom és a sumér városállamok földrajzi elhelyezkedése. Forrás: Net3.

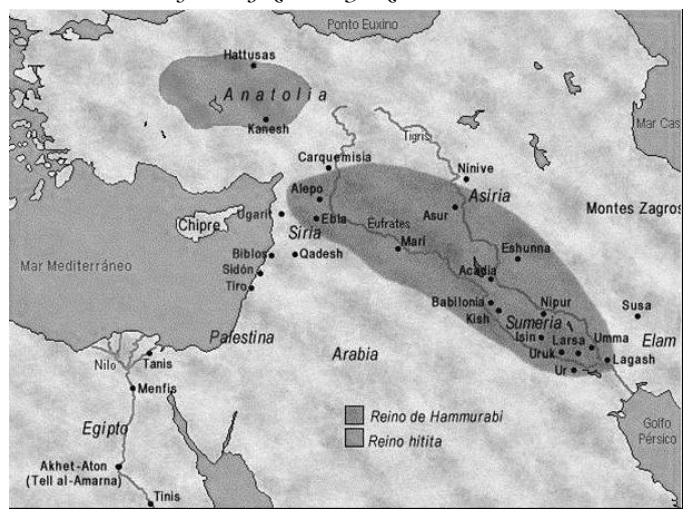

Miután elfoglalta a legfontosabb kereskedelmi utakat, célul tűzte ki, hogy alattvalói körében is megszerzi a népszerűséget. A király ezért gondoskodott arról, hogy minden alattvalója jól éljen és rendezett otthonban lakjon. A telkek, házak értéke nagyban növekedett, a nép vagyonosodott és jólétnek örvendett. A király bölcsen kímélte a sumér kulturális és vallási hagyományokat. Ezért ha-

ladéktalanul intézkedett, hogy állítsák helyre a lerombolt, ám a nép által tisztelt napisten larsai templomát, az istentisztelet középpontjává, valódi főistenné azonban Bábel város istenét, Mardukot tette (Márki, 1910).

Az uralkodó a hódító politikájának eszközéül szolgáló hadsereg tökéletes megszervezését tartotta a legfontosabbnak. Mint a hadsereg legfőbb parancsnoka irányelveivel és rendeleteivel sokszor szólt bele szervezési kérdésekbe, elsősorban a vidéki városok helytartóinál. A hadkötelezettség elvben általános volt, ellenőrzés céljából rendkívül pontosan vezették a hadkötelesek névsorát. A felmentés egyedül az uralkodó hatáskörébe tartozott.

Hammurapi a hadsereget két nagy részre osztotta fel: nehéz és könnyügyalogságra és a vízi harcra kiképzett alakulatokra, azaz valamilyen - mai fogalmaink szerinti -,,tengerészgyalogságra"(Klíma, 1983).

Az óbabiloni sereg kezdetben állandó, hivatásos jellegü és a „király csapata” („qicir sarri”) elnevezésû alakulatból és az alkalmilag behívott tagokból állt.

Az óbabiloni kor katonái már nem falanxban, hanem a mozgékonyabb és az egyéni erő és ügyesség kifejtésére több módot nyújtó csatársorban harcoltak. Fő fegyverük a lándzsa mellett a nyíl, amelynek segítségével a harcot már nagyobb távolságról is megkezdhették (Dávid, 1928).

Fontos kiemelni, hogy csak az óbabiloni birodalom legvégén jelent meg a harcmezőn a ló (Nagy, 2014), így lovasságról ebben az időszakban még nem beszélhetünk.

A katonai hierarchia követte a Sarrukín által bevezetett rendszert, azonban a különböző kiváltságokkal rendelkező hivatásos tisztikar mellett a katonai közigazgatás vezetői is jelentős szerepet kaptak a hadsereg irányításá- 
ban. A hadvezér, a tábornok (,ugala mar.tu”) - aki hivatalos megnevezése szerint: „az. Amurru felügyelóje” címet viselte -, a századosok (,pa.pa, wakil battim”) és az őrmesterek (,nu.banda”) katonai vezetőként, a katonai adminisztráció vezetője (,abi sabi”), a behajtók („,deku”), a királyi katonai írnokok (,dumu.e.dub.ba”), továbbá a katonai írnokok (,dub.sar erin”) katonai tisztségviselőként látták el feladataikat.

Egyes források szerint a katonai adminisztráció vezetője nagyobb hatalommal rendelkezett, mint a tábornok. Jelentőségét az is igazolja, hogy egyes katonai ügyekben döntőbírói szerepet is ellátott, továbbá a tábornokhoz hasonlóan „első tanúként” szerepelt olyan jogi ügyletekben, amelyek az ún. ,sibtu birtokkal' - a birtokrendszer egyik elemével voltak kapcsolatban (lásd: Rivkah, 1975).

A hivatásos katonák közül a katonai arisztokrácia tagjai - a tábornok és a századosok jelentős ingó és ingatlan vagyonnal rendelkeztek, általában sikeresen gazdálkodtak és kereskedtek, továbbá rendszeresen részesültek a háborús zsákmányból is.

Az aggadei korban Sarrukín és utódai a meghódított városok templomgazdaságait gyakorlatilag királyi birtokként kezelték, és abból javadalmazták a birodalom támaszaként szolgáló katonai-adminisztratív vezetôréteget, amely a kapott birtokot gyakorlatilag már magántulajdonként használta (Lóránt, 1918). Az óbabiloni korban ez annyiban változott, hogy az alattvalóitól elkobzott földeket - általában - nem tartotta meg az uralkodó, hanem „nagylelkűen” adománybirtokként továbbadta az arra érdemeseknek, így a katonai-adminisztratív réteg vezetőinek is.
Az állandó királyi sereg mellett - szükség esetén - az egyes városoknak kellett a megfelelő létszámú katonai kontingenst felállítaniuk. A rendkívül szigorú katonai szolgálati kötelezettség alól a papokon kívül csak a tisztviselők, bizonyos városok polgárai és az udvari alkalmazásban levő mesteremberek és földművesek voltak felmentve (Dávid, 1928). A kiegészítő katonai szolgálat alatt a tartalékosok fegyverzeti, elhelyezési, élelmezési és egészségügyi ellátását az uralkodó biztosította. A tényleges szolgálat idején azonban nem részesültek központi termény vagy pénzellátásban, így az keresetkiesést jelentett a tartalékosoknak:

„Egy munkás havi bérének összege általában 1 siqlum (8,4 gramm) ezüst körül mozgott, amiből 120 liter gabonát, vagy 0,4 liter olajat, vagy $3 \mathrm{~kg}$ gyapjút lehetett vásárolni. $\mathrm{A}$ bérek egy hányadát pénzben fizették, ami a piacgazdaság bizonyos fokú meglétének bizonyítéka. Egy munkás havi keresetéből kb. 3-4 embert tudott élelmezni, vagyis, figyelembe véve, hogy e mellett még saját parcellája, kertje is lehetett, el tudta tartani a családját" (Lóránt, 2018, 62. o.)

Hammurapi uralma végén tette közzé a döntően szokásjogi alapokon nyugvó, de esetjogi jellegű szabálygyűjteményét, amely 282 paragarafusban szabályozta Babilónia köz- és magánéletet érintő valamennyi kérdését. 
A mitológia szerint Hammurapi, Babilónia királya a főistentôl, Marduktól kapta az „igazság pálcáját”, mellyel szert tett a törvényalkotó és a bírói hatalomra. E hatalmával élve megalkotta máig is híres törvénykönyvét, melyet dioritoszlopokra vésetett, és ezeket a birodalom nagyobb városainak templomaiban, valamint Marduk babiloni fötemplomában állíttatta fel, hogy minden szabad ember láthassa és olvashassa azokat a szabályokat, amik rá vonatkoznak. E kőoszlopok közül egy maradt ránk, melyet francia régészek tártak fel 1901-ben, és amely ma a párizsi Louvre-ban látható. E kőoszlop 2,2 méter magas, és ebbe vésték ékírással, akkád nyelven Hammurapi király törvényeit (Tóth, 2007).

Az uralkodó törvényét - amelyet a kor szokása szerint inkább oktatószövegnek szánt írnokok, tisztviselők, bírák számára - akkoriban nemcsak Sumérban ismerték el, hanem az ókori Közel-Kelet összes országában, még Hammurapi halála, sőt a sumér nép eltűnése után is. Világos stílusa és pontos fogalmazása miatt irodalmi normának számított és a Gilgames-eposz mellett az óbabiloni kor egyik legfontosabb szövegemléke (Horváth, 2012).

Hammurapi törvénye rendelkezett a katonai szervezetről és a katonai kötelezettség két formájáról is. A népfelkelés tagjait „,az összes szabadok" közül a királyi mozgósító tisztek, az egyes területek helytartóinak felügyelete alatt sorozták. A hadsereg magvát azonban már az állandó szolgálatra kötelezett ún. ,telkes-katonák” szolgáltatták (Hahn, 1963). A szolgálati birtokot, az ,ilkum-ot az uralkodó azért adományozta, hogy a telek használóját (birtokosát) a hadjáratokban való részvételre kötelezhesse; a hadjárat természetesen nem csupán háborút jelentett, hanem közmunkát is (Komoróczy,1975). A ,telkes katona” havi tíz napot vagy évi négy hónapot - a király által meghatározott beosztás szerint - köteles volt katonai vagy rendőri szolgálatban tölteni.

A telkes katonaság létszáma jelentékeny lehetett, hiszen a Kr. e. 18. században az óbabiloni vezető államok által mozgósított seregek (Lóránt, 2018) egyenként több ezres nagyságrendűek voltak. Egy korabeli hadjáratról fennmaradt feljegyzés szerint a városok közösen 22000 főt számláló „erős hadsereget" is képesek voltak felállítani (Stillman és Tallis, 1984). A telkes katonák gazdálkodhattak a nekik adományozott elidegeníthetetlen birtokon, azonban a földet nem adhatták zálogba, sem ajándékba a feleségüknek vagy hozományként a lányuknak. Amennyiben az apa a harcban elesett, kizárólag a fia folytathatta a gazdálkodást, ha pedig a fiú még kiskorú volt, anyja kötelessége volt a fiú felnevelése, s ezért ő rendelkezett a birtok egyharmadával. Hammurapi megtiltotta a katonáira bízott jószágok (juh, kecske, sertés és szarvasmarha) eladását is.

A katonakötelezettség ebben az időben halálbüntetés terhe mellett előírt személyes katonai szolgálat volt, nem lehetett „,helyettesre" átruházni.

„Az Újbabiloni (Káld) Birodalom idején (Kr. e. 626-539) a személyes szolgálati kötelezettséget már „hadmentességi adó” megfizetésével is ki lehetett váltani, a- 
melynek összeg igen magas volt, ezért azt általában csak a hadiszállításokkal, a zsákmány összevásárlásával foglalkozó tehetős réteg engedhette meg magának" (Dávid, 1928, 121. о.).

Aki a behívóra nem jelent meg, vagy zsoldost küldött maga helyett, az életével lakolt. Vagyonát nem az örökösei kapták, hanem arra szállt, akit maga helyett akart a harctérre küldeni.

Hammurapi gondoskodott azokól is, akik az ellenség fogságába estek (4. ábra). Ha sikerült megszökniük, visszakapták egykori birtokukat, még akkor is, ha azon már valaki más gazdálkodott, tekintet nélkül arra, hogy az eredeti birtokos meddig volt távol. Ha kereskedő váltotta ki és hozta haza a foglyot, költségeit a faluközösség térítette meg; ha annak nem állt módjában, akkor a faluközösség temploma; ha a templom sem tudta megfizetni, akkor a kereskedőnek a palota kincstára térítette meg a válságdíjat. De még ennek megtérítése fejében sem nyúlhattak ahhoz a birtokhoz, amelyen a katona fogságba esése előtt gazdálkodott (Klíma, 1983).

Hammurapi azt a királyi mozgósítótisztet, vagy helyettesét, aki „szolgálatra nem kötelezett”, kiszolgált katonát vett fel a hadjáratra, halálbüntetéssel sújtotta (Hahn, 1963). Ez az intézkedés megvédte a szolgálatból elbocsátott katonákat a tisztviselők túlkapásaitól.

Az óbabiloni kor végén már külföldi zsoldosok is harcoltak a hadseregben. A birodalom külső területein elhelyezkedő megerôsített városok nagymértékben támaszkodtak a főleg a kassu törzsből származó (kasszita)
4. ábra: A Hammurapi kódex felirata. Forrás: Net4.

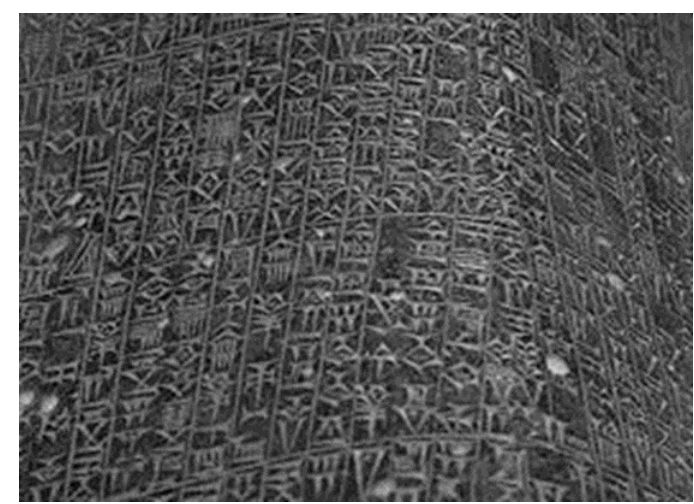

harcosokból álló zsoldosokra (Rivkah, 1975), akik alapvetően a hettiták és a saját törzsük (!) a kassuk betörése ellen védték a birodalmat.

$\mathrm{Az}$ első dinasztia bukását végül a Kr. e. 1595-ben bekövetkező hettita támadás okozta: a kis-ázsiai nép I. Mursilis vezetésével megalázó vereséget mért Babilonra. A várost feldúlták és elvitték a babiloni főisten Marduk, valamint hitvese, Szarpanítu szobrát. Mursilis azonban nem kívánt letelepedni Babilóniában, így a hatalmi vákuumot végül a birodalmat betöréseikkel már korábban is fenyegető kassuk töltötték be, akik megalapították Babilon történetének leghosszabb ideig, több mint 400 éven át hatalmon lévő dinasztiáját.

A kassuk első lépésként Kr. e. 1570 környékén visszahozták Marduk és hitvese szobrát. Az idegen dinasztia végig törekedett a babiloni kultúra és hagyományok tiszteletben tartására. Alkalmazkodtak a valláshoz, átvették az ékírásos akkád nyelvet, amely uralkodásuk alatt egy időre a diplomácia nyelvévé vált a Közel-Keleten. Virágzott a kereskedelem, és ahogy a korábbiakban már utaltunk rá, a babiloniak ezekben az évszázadokban 
ismerkedtek meg a lóval. A kassu kor a béke és stabilitás időszaka volt, melynek során Babilon ismét Mezopotámia kulturális és politikai központjává emelkedett.

Babilóniában a kassu uralom megszilárdulásával kialakul a közös földtulajdon új pontosabban felújított -formája. A föld a családi szervezet: a „torony”, szó szerint a „megerôsített falu”, a „faluközösség" („dimtu”) tulajdonába került, melynek élén a királyi hivatalnok állt. Erről a közös gazdálkodásról tudósítanak a „határkövek” („,kudurruk”). Az oltalmazó istenségek szimbólumaival díszített dombormú alatt olvasható szöveg hírül adta, hogy a föld köztulajdonból átkerült a templom tulajdonába, vagy esetleg az érdemeket szerzett tisztségviselők, katonatisztek tulajdonába jutalmul a szolgálataikért. Legnagyobb területként 6000 hektárt jegyeztek fel, ami a kassu faluközösségek nagy kiterjedésű telkeire utal. A határköveket a templomokban és a szerződésben szereplő telken is elhelyezték. A kor szokásai szerint, a határkövön akkád nyelven szörnyű átkokat mondtak annak a fejére, aki azt eltávolítja, arrébb helyezi, vagy eltünteti annak a szövegét (Klíma, 1983).

Természetesen a későbbi hódítók ettől egyáltalán nem rettentek meg. A kassu dinasztia bukása után Babilonban egy hosszú, háborúskodással teli időszak következett. Az újabb aranykor csak az Újbabiloni Birodalom (Kr. e. 625-539) idején, a káld dinasztia uralkodásával érkezett el (Net5).

\section{Az özvegyek és árvák helyzete az Óbabiloni Birodalomban}

A törvénygyüjtemény rendelkezett „a hadi fogságba került, híre veszett és száműzött férjek nejeiről”, amely rögzítette az évszázadok során kialakult szokásjogot, a nők (özvegyek) helyzetét.

„Az uralkodók már Mezopotámia korai idôszakában rendelkeztek az elesettekről, a társadalom szegénysorban élő tagjairól. $\mathrm{Az}$ ősi Ur városállam jogéletében (Kr. e. 2600 körül) Urukagina törvényei biztosították a szegények, özvegyek és árvák jogait. Majd Ur-Nammu törvényeiben ismétlődik az özvegyek, árvák és szegények védelme (Kr.e. 2350)”. (SzádeczkyKardoss, 2012, 183. o.)

A háborúskodást figyelembe véve azokat az élethelyzeteket szabályozta az uralkodó, amelyekben a férjét hazaváró asszony végül más férfi otthonában talált menedéket. Az ilyen cselekedet abban az esetben volt megengedett, amikor a férj nem hagyott maga után elegendő élelmet. Azonban, ha a férj kiszabadult a fogságból, feleségének vissza kellett hozzá térnie abban az esetben is, ha új társának már gyermekeket is szült. Ebben az esetben a gyermekek apjukkal maradtak (Szinai, 2013). Amennyiben a férj elegendő élelmet hagyott feleségének, a hűtlenséget szigorúan büntették, halálbüntetéssel (vízbefojtással) sújtották a megtévedt asszonyt. A férj halála esetén, amennyiben a házasságból nem származott gyermek az özvegy a hagyatékból megkapta a hozományát és ezen felül ellátásra is igényt tarthatott, a férj vagyona pedig a férj családjára szállt vissza. A fiúgyermekek a rájuk maradt vagyonból egyformán részesültek, a leánygyermekeknek azonban örökösö- 
dési joguk nem volt, csak az apai vagyonból történő megfelelő kiházasításra és hozományra tarthattak igényt. Azonban az apa szándéka szerint kivételesen örökölhetett - sőt teljesen szabad rendelkezési jogot kaphatott öröksége fölött - az olyan leány, aki valamilyen papi rend szolgálatába állt (Dávid, 1928).

„Ezek a nők, akiket »naditumnak« hívtak a keresztény női szerzetesrendekhez hasonlóan elkülönülten, kolostorokban éltek és gondosan kezelték az örökségüket, amelyet általában olyan családokra hagyományoztak, amelyek szintén papi pályára szánták leánygyermeküket, vagyis a földeket végül is a naditumok összessége a »naditusz« örökölte. Az ősi Mezopotámiában a naditusz intézményének nagyon komoly gazdasági és politikai befolyása is volt. A különböző kölcsönök legfontosabb forrása a naditusz volt, és a fennmaradt források igazolják, hogy rendszeresen nyertek a bíróságokon, amikor a naditumok fivérei vissza akarták perelni a leánytestvérük által a nadituszba vitt földeket”. (Lóránt, 2018, 54. o.)

Mezopotámiában a testi és értelmi fogyatékkal élő emberek - akik közé a háborúkban megsérültek is beletartoztak - nem feltétlenül marginalizálódtak. A peremre szorulás leginkább csak akkor következett be, amikor a legfőbb szociális biztonságot jelentô családi kötelékéből kikerültek. Helyzetük azonban még ekkor sem volt reménytelen, mert a korabeli uralkodók szívesen tüntették fel magukat ,az özvegyek, az árvák, a gyengék és a betegek” védelmezőjeként. Ezt igazolják azok a források is, amelyek tanúsága szerint a templomgazdaságok munkásainak többsége beteg és fogyatékos ember volt. Az ő alkalmazásuk gyakorlata sajátos kettősségre utalt: kifejezte az olcsó munkaerőből fakadó gazdasági haszonra való törekvést és az elesettekről való gondoskodás gesztusának egy sajátos keveredését (Magyar, 2017).

\section{Irodalom}

Dávid Antal (1926): Bábel és Assur I. Történet, Szent-István-Társulat az Apostoli Szentszék Könyvkiadója, Budapest. Letöltés ideje: 2020.04.02. Web: http://www. ppek.hu/facsimile/David_Antal_Babel_e s_Assur_I_facsimile.pdf.

Dávid Antal (1928): Bábel és Assur II. Történet, Szent- István-Társulat az Apostoli Szentszék Könyvkiadója, Budapest. Letöltés ideje: 2020.04.02. Web: http:// www.ppek.hu/facsimile/David_Antal_Ba bel_es_Assur_II_facsimile.pdf

Farkas Ádám (2016): Tévelygések fogságában? Tanulmányok az állam fegyveres védelmének egyes jogtani és államtani kérdéseiröl, különös tekintettel Magyarország katonai védelmére. Magyar Katonai Jogi és Hadijogi Társaság, Budapest.

Hahn István (1963): A hadmüvészet ókori klaszsqikusai. Zrínyi Katonai Kiadó, Budapest.

Hajdú Lajos, Horváth Pál, Ijjas József, Nagyné Szegvári Katalin, Zlinszky János és Stipta István (1991): Altalános Jogtörténet. Tankönyvkiadó, Budapest.

Klíma, Josef (1983). Mezopotámia. Ösi civilizáció és kultura a Tigris és az. Eufratész. mentén Gondolat Kiadó, Budapest. 
Komoróczy Géza (1975): A földtulajdon az Ókori Mezopotámiában és az ún. ázsiai termelési mód elmélete. A Magyar Tudományos Akadémia Filozófiai és Történettudományok Osztályának közleményei, XXIV. Kötet I. szám. Akadémiai Kiadó, Budapest.

Komoróczy Géza (s.a.): Mezopotámia története az öskortól a perzsa bóditásig (Kr. e. 539) Elektronikus kiadás: Terebess Ázsia ETár. Letöltés: 2020.02.02. Web: https:// terebess.hu/keletkultinfo/mezopotamia.h tml

Lóránt Károly (2018): Mezopotámia, a piacgazdaság hajnala. Hitel folyóirat, 31. (7.). Letöltés: 2020.03.03. Web: http://www. hitelfolyoirat.hu/sites/default/files/pdf/1 0-lorant.pdf 1

Magyar Adél (2017): Az értelmi fogyatékos gyermekeoól és felnöttról alkotott mentális kép alakulása - az elááró, gyógyitó és fejlesztó intézményrendszer történetének tükrében - a kezdetektöl a 19. század végéig. Doktori (Phd) értekezés, Pécsi Tudományegyetem, Pécs. Letöltés ideje: 2020.03.20. Web: https://pea. lib.pte.hu/bitstream/handle/pea/16344/ magyar-adel-phd-2017.pdf?sequence $=1 \&$ isAllowed $=\mathrm{y}$

Márki Sándor (1910): Az Ó- és Középkor története (Elsö Rész). Athenaeum Irodalmi és Nyomdai Részvénytársulat, Budapest. Letöltés ideje: 2020.01.02. Web: http:// mek.oszk.hu/13300/13364/pdf/13364_1 -1.pdf

Nagy László (2014): A tudományos felfedezések, a technikai újítások hatása a stratégiai gondolkodásra I. rész. Hadtudományi Szemle, 7. (1.). 39-40.
Rajkó Andrea és S. Nagy Katalin (2009): Müvészettörténet I. kötet. A kezdetektől a 19. századig. Typotex Kiadó, Budapest.

Richard A. Gabriel (2012): Man and Wound in the ancient World - A History of Military Medicine from Sumer to the Fall of Constantinople, Washington, D.C.: Potomac Books.

Szádeczky-Kardoss Irma (2012): Tűzzelvassal avagy türelemmel. Egy romlott szövegú Szent István-i kapitulum rekonstruálása és értelmezési konzekvenciái. $M a$ gyar Sion Új folyam. VI.(XLVIII.) évfolyam. 2. szám. 183-201.

Rivkah, Harris (1975): Ancient Sippar - A Demographic Study of an Old-Babylonian City (1894-1595 B.C.) Nederlands HistorischArchaeologisch Instituut, Istanbul.

Stillman, Nigel, Tallis, Nigel (1984): Armies of the Ancient Near East, 3000 BC-539 BC organisation, tactics, dress and equipment. Wargames Research Group, Photoset and printed in England by Flexipit Ltd. Worthing, Sussex.

Szinai Alexandra (2013): A sqociális biztonsághoz való jog, Miskolci Egyetem, Miskolc.

Tóth J. Zoltán (2007): A halálbüntetés az ókori államok jogában. Acta Universitatis Szegediensis Acta Juridica Et Politica Tomus LXX. Fasc. 18., 9. o. Szeged. Letöltés ideje: 2020.03.13. Web: http://acta.bibl.uszeged.hu/37947/1/juridpol_070_fasc_ 018.pdf

Vér Ádám (2011): Az Újasszír Birodalom keleti expanzioja. Doktori disszertáció. Letöltés: 2020.03.01. Web: http://doktori.btk.elte. hu/hist/veradam/diss.pdf 


\section{Internetes hivatkozások}

Net1: A „termékeny félhold” földrajzi elhelyezkedése. Letöltve: 2020.04.18. Web: https://slideplayer.hu/slide/12248045/72/i mages $/ 25 /$ Term $\%$ C3\%A9keny+F $\%$ C3\%A 9lhold.jpg

Net2: Sumér szekér ábrázolása. Letöltve: 2020.04.17. Web: http://sumerianshakes peare.com/84201.html

Net 3: Az Óbabilon birodalom és a sumér városállamok földrajzi elhelyezkedése.
Letöltés ideje: 2020.04.17. Web: http:// tortenelemcikkek.hu/node/131

Net4: A Hammurapi kódex felirata. Letöltés ideje: 2020.04.18. Web: https://www. wikiplanet.click/enciclopedia/simple/Code _of_Hammurabi

Net5: Amit Szaddám is csak irigyelni tudott Babilon lenyűgöző öröksége, Múlt-kor történelmi portál. Letöltés is ideje: 2020.03.10. Web: https://mult-kor.hu/amit-szaddamis-csak-irigyelni-tudott---babilon-lenyugozooroksege-20150914?print=1 